\title{
AVALIAÇÃO DA TAXA DE GERMINAÇÃO DE ESPÉCIES ARBÓREAS NATIVAS, PARA REABILITAÇÃO DE ÁREAS IMPACTADAS POR EXTRAÇÃO DE ARGILA EM MARABÁ - PA
}

\author{
Jayane Santos Nunes'; Clarissa M. Knoechelmann² \\ ${ }^{1}$ Discente do curso de Agronomia, Faculdade de Ciências Agrárias de Marabá (FCAM), Universidade Federal do Pará \\ (UFPA), bolsista SINDICERV, jayrzinhanunes@ hotmail.com \\ ${ }^{2}$ Professora Assistente, FCAM, UFPA, clarissa@ufpa.br
}

RESUMO: Áreas degradadas são tipicamente caracterizadas por solos pobres, erodidos, com instabilidade hidrológica, produtividade reduzida, pouca diversidade biológica e alteração das características físicas e químicas. O solo pode sofrer erosão estando relacionado a diversos fatores responsáveis, que vão dos mais simples aos mais complexos. A atividade de extração de argila que implica na retirada da vegetação natural e intensa movimentação de solo gera em alguns casos buracos que contribuem para o distúrbio da área, além de promover com a retirada de nutrientes, alta toxidez de metais no solo. A exploração de argila na cidade de Marabá tem causado uma série de impactos negativos ao meio físico, natural, facilitando o processo de erosão, e o solo apresentase erodido, com considerável quantidade de rejeitos, prejudicando também a microbiota do solo. Com esta problemática o projeto "Reabilitação de áreas impactadas por extração de argila através do uso de plantas arbóreas inoculada com fungos micorízicos", convênio UFPA - Sindicato das Cerâmicas Vermelhas (SINDCERV) tem como objetivo a produção de mudas arbóreas nativas inoculadas com fungos micorrízicos. O objetivo do presente trabalho é analisar a taxa de germinação das mudas das espécies arbóreas, acompanhando todo o processo desde a quebra de dormência até a germinação, em casa de vegetação. Espera-se que a taxa de germinação das mudas após a semeadura, no período de 120 dias, venha suprir a primeira parte do projeto, que consiste no transplantio de mudas suficientes para a área a ser reabilitada.

Palavras chaves: casa de vegetação, mudas, solo, mata ciliar. 